\title{
A City as the Key to Interpreting a Novel by Alessandro Baricco
}

\section{Abstract}

The aim of this paper is to present the term 'city' both as a constructive element and a key to interpreting the same-named novel. The paper is focused on the term's etymology and contemporary definitions, and on the novel's interpretations in the postmodern framework. In order to understand all the layers, the intertextual and intermedial theories are also important. Gould and his governess Shatzy Shell are the main characters of the novel. Gould is a teenager who has been recognized as a genius, which has brought him loneliness and desire to achieve success. That loneliness could be compared to some descriptions of postmodern cities, and on the other hand the cities could be compared to postmodern literature. The novel's most important city is Closingtown - a city that does not appear on any map. It is a town in the West where the time has stopped. The town is compared to a fragmented postmodern literary work and this novel, as Baricco said, is a representation of what a city might be. A double postmodern language game is present in the novel. The first is related to the Closingtown as a Western city and Shatzy's aspiration to write a western. The second is related to the comparison of the Closingtown and the postmodern text. Someone in the city has torn up time, which can be reflected in the fragmented narration, and it can be read that the citizens have a choice between leaving the town and patching time. The choice requires a dedicated reader who will deduct the story from the patchwork; as the citizens patch time, the dedicated reader finds a new patch of the overall story. These language games have a reflection on a game that uses physical strength and strategic approach - boxing. The interpretation game is also possible if we take into consideration intertextuality and intermediality that require a dedicated reader who is able to understand and enjoy all the segments that construct this complex novel. 
Keywords: city, language games, postmodern novel, western

\section{Introduction}

This paper will present the novel named City written by Alessandro Baricco. The main hypothesis is that the term 'city' with all of its connotations is the key to interpreting this novel. Baricco's City is considered his most complex postmodern novel and what makes it a whole is the construction of a mental city with all the different characters who represent it.

In order to prove this hypothesis, an analysis of the term 'city' will be conducted; also, the postmodern framework will be studied. Postmodernism is connected with intertextuality and intermediality, so these concepts will be presented. They, as it will be shown, introduce the concept of language games, which in this novel are multiple.

We will see that the novel consists of the story within a story, because of the protagonist's desire to write a western. Because of this, western theory analysis will be conducted. The author of this paper would like to prove that all the layers of this postmodern patchwork are interconnected and have multiple meanings that require a dedicated reader.

\section{A City as the Key to Interpreting Alessandro Baricco's Novel}

In order to understand the term 'city' which is the key to interpreting the same-named novel and its constructive element, this paper will present the term's etymology, its meanings and connotations in contemporary dictionaries, as well as some important theories and ideas about the term 'city' starting from antiquity to the third millennium.

\subsection{Definition of the Term 'City' in the Context of Baricco's Postmodern Novel}

The English term 'city' originates from the Middle English word cite which has been adopted in 1200 from the Old French word cité with the meaning of "town, city." The French language has 
borrowed the term from Latin cīvitās, which means "state." The Latin term derived from civis, "citizen" (Online Etymology; Chambers; Wordnik).

The Encyclopedia Britannica says that 'city' is a "relatively permanent and highly organized centre of population, of greater size or importance than a town or village." The name 'city' is attributed to "certain urban communities by virtue of some legal or conventional distinction that can vary between regions or nations." Similar explanations can be found in contemporary dictionaries.

The contemporary dictionaries which have been taken into consideration show that the term 'city' indicates "a large town" (Cambridge, Collins, Chambers, Wordnik, Macmillan, Wordsmyth, Merriam-Webster, Your Dictionary, Vocabulary.com, Infoplease). Its importance is measured on the basis of its religious, financial, and political meaning. The dictionaries also show that a 'city' is not just a place, but also includes its citizens. Some dictionaries with the term 'city' refer to a "Citystate" (Infoplease, Merriam-Webster, Wordnik).

According to Macmillan and Merriam-Webster dictionaries, the term refers also to "a place that has a lot of a particular quality." Used with the article 'the', the term refers to "financial and commercial centre of London" (Wordnik, Merriam-Webster, The American Heritage). It refers also to the "the influential financial interests of the British economy" (Merriam-Webster, The American Heritage). A similar usage is found also in the United States and Canada where it stands for high-rank municipalities (Merriam-Webster, The American Heritage, Wordnik). The term 'city' can be used as a slang for intensifying the meaning of the sentence (The American Heritage, Wordnik). Urban Dictionary brings an explanation of the term 'city' used as an adjective. It is "a way to say something possesses a distinguishing attribute exceedingly" (Urban Dictionary), which, as we shall see, is important for the main character's interpretation in Baricco's novel.

According to Vladimir Kusik, the term 'city' also has its mythological meaning because it had been constructed as the home of gods, and it could be identified with the world. Nowadays, in the global society, the world can be identified as a city (Kusik 17). And the great philosopher Aristotle also stated that cities should be built to protect the citizens and make their lives happier (Kečkemet 5). This idea is connected with the ones that Kečkemet and Augé have presented. Kečkemet states that a city should be an organized settlement that provides both physical and psychological 
development for its inhabitants (59), while Augé writes about a utopian city where people could socialize and meet. (10)

In fact, Augé speaks of anonymous solitude in modern cities due to modern technologies and introduces the idea of a "utopian city-world," a transformed city that in itself synthesizes the world and gives people an opportunity to meet and socialize (Augé 29-41), but nowadays most of the critics have stated that globalization and great cities make individuals feel isolated (Kečkemet 571). According to Kečkemet, this is relevant because in contemporary society a large part of the population lives in cities (59), and Augé creates his utopian ideas about 'city-world' to contrast isolation between people that modern society brings.

While writing about cities, Duško Kečkemet identified a "modern citizen" with a modern city, as the lives of a large part of the population are strongly connected to the destiny of a certain city (59). In that sense, the city is a product of civilization (Kečkemet 14, 59, 98). According to Setha M. Low, the term 'spatialize' has not only physical characteristics but it also includes social relations in a specific area (91-92). To Vladimir Kusik, the city is both a physical and a mental place with multiple meanings important not only to individuals but to the collective (5).

There is an opinion that there are three types of reasons to establish a city: economic, political, and cultural (Kečkemet 14). A similar point of view is that of Valentina Gulin Zrnić, who writes that a city may be composed of different urban, social, cultural, and national layers, and that it can be considered as a process, because it is incomplete, and the role of people is to transform cities in accordance with people's capabilities (Gulin Zrnić 7-8).

According to Pascual Maragall, a city might present evidence of all the changes which the city has been subject to (qtd. in McDonogh 217). Kusik has identified history with the city. The claim has its argument in the fact that a city becomes what history brings upon it (Kusik 18-19). Similar is the point of view of Kečkemet, who thinks that the city is a civilization product which reflects all of civilization's successes and vice versa (Kečkemet 14, 98).

There are some interesting statements about the city. Kusik says that beauty is a characteristic that makes a city what it really is (37-38). In her essays, Ivana Šojat-Kuči writes that the city is a monument which demonstrates all the traces of human presence in a certain place. In addition, 
she writes that the city is a representation of dualities a human being can experience during his or her life, as the inevitable contrast between life and death (Šojat-Kuči 33, 37).

All of the above mentioned brings us to the conclusion that the term 'city' has a tradition from Aristotle to the third millennium. It has been used not only to indicate a place where people live but also to refer to people who live there and modify it. The existence of a certain city is closely related to its citizens who left their material trace in its shape and existence. A nonmaterial trace which the citizens of a certain place have left can be deducted from the civilization and its evolution.

The fact is that a large part of the population lives in cities, and in that sense, cities represent modern societies. Some modern cities may bring isolation and fragmentation of its population. Isolated and fragmentary subjects are characteristic of postmodern literature. In the next paragraphs we will see Baricco's novel in the postmodern framework that will emphasize that idea.

\subsection{About Baricco's Novel in the Light of Postmodernism}

City is the first Italian book promoted online. The website abcity.it exists from April 1999, and it is still active. Also, there has been an active forum named La City dei lettori (The City for readers). The website will be active until the readers lose interest in it. That proves that the book keeps the readers interested. Another evidence of its success is given by the fact that it has been translated and reviewed multiple times (Lo spazio).

According to Ewa Nicewicz's interpretation, the novel can be compared to "a big kaleidoscope or the Web," because of its narration that could be compared with a flow of thoughts, where many images are presented without order (164). The novel is believed to be Baricco's most complex literary work (Raspudić 226). There are several layers of narration, a story within another story, and two different endings.

The second and third layers depend on the first one, which is about Shatzy and Gould and is the only layer that could be taken as an isolated narrative section (Purgar 171-72). The motifs from the two dependent layers, says Raspudić, are connected to Baricco's two passions - western and boxing (221). 
At the beginning, there is a phone call. Gould, a twelve-year-old boy who has an IQ of 180, calls the CBR company which has been conducting an audience analysis to see if Mami Jane, a character in the Ballon Mac comic, should or not die. One of the telephonists who work there is Shatzy Shell. She answers Gould's call. During the phone call, Shatzy gets fired. Her habit is talking too much on the phone about topics which are not related to her job. Gould invites Shatzy to meet him in a cafeteria. The same day when they met, Shatzy accepts to be his governess because the boy has been living all alone with two imaginary friends. By the end of the novel, the situation is explained. His father works for the army and takes care of his wife, Gould's mother, who is in a psychiatric clinic, so the boy has lived alone at university until Shatzy becomes his governess.

That layer also includes Gould's education and some very interesting lectures. It takes two years' time. Gould is believed to get a Nobel Prize someday. But, in the end, he leaves his further education and starts living on his own, working in a public toilet, always with his two imaginary friends and the boxing matches which take place in his head.

The imaginary boxing matches present the second layer $\left[^{[1]}\right.$ Gould used to fantasize about matches of the boxer named Larry Lawyer Gorman while being in the toilet. According to Raspudić, those descriptions take place in the second layer of the novel, and they are one of the most interesting sequences in the book, revealing Baricco's passion (221-23). The boxing matches are so important to Gould because he used to listen to them with his father when they lived together.

Thirdly, the novel is related to the genre of western. In fact, Shatzy has always dreamt to write one. She started when she was six years old, and she continued working on it until her death. Firs she was writing it, then she used a tape recorder to record her ideas. But she did not have an organized way of writing her western. The western has never had a material form either. Gould's mother could hear its end when Shatzy was visiting her in the clinic. This could be related to numerous interpretations of literary work and Barthes's theory of the death of the author, as her western has not been finished, and according to Barthes, literary works remain open for the readers' interpretations. In fact, before the end of the novel, Shatzy dies. She has a car accident and remains paralyzed. She wants to be euthanized. Having sympathy for her, Gould's father finds a way to make it happen. The ending of the western is presented after Shatzy's death. 
Raspudić writes about the first ending, which is related to Shatzy and the western. The second ending is related to Gould and his imaginary boxing story (Raspudić 219-22). The author also states that the novel contains some adopted approaches not only from other literary genres but also from the spheres of comic books, commercials, and film ${ }^{2]}$ (Raspudić 219). While talking about the novel's complexity, Ewa Nicewicz mentions Bildungsroman, western, university lectures, essays, football matches, radio transmissions of boxing matches, monologues, childhood memories, interviews, didascalies (Nicewicz 164). These approaches are related to intertextuality and intermediality.

Intertextuality is a process that involves certain codes or conventions, but also certain motifs and topics. That is the reason why the process of understanding certain texts includes the understanding of all the systems that the text is emerged into (Beker 10). Intertextuality presents a contrast to cliché because thanks to intertextuality, the text gets a new meaning (Beker 14), and also an artistic work becomes critical and fragmentary (Lachmann 78). The intertextual approach related to wordplay includes coding that intertwines two semantic fields in order to create a new sense from the existing ones (Lachmann 84). According to Pavao Pavličić, there is a relation between texts because both of them belong to the literary field. On the other hand, the reason a certain text is literary is because it establishes relations with other texts (Pavličić 157). Examples of intertextuality could be found in the novel in Prof. Matens' Lecture No. 14. (Baricco 56-57), and Prof. Mondrian Kriloy's Lecture No. 11 (Baricco 94-105).

Pavao Pavličić states that intermediality is a process that includes a transfer of structures and materials characteristic of one media into another (170). Intermediality between literature and media like film, music, radio, and television includes a metaphoric transfer (Pavličić 173). This transfer is present in Baricco's novel in the depictions of Gould's imaginary boxing matches and Shatzy's westerns, where music could not be transmitted but has been mentioned (for example, Baricco 173-272). According to Krešimir Purgar, western is an internal narration of the female protagonist, while boxing matches are a schizophrenic internal narration of the male protagonist (172). The matches, according to Purgar, present cinematic experience for readers by introducing cinematic experience into the literary text (180) According to Pavao Pavličić, the montage in a certain literary text includes a certain style, like short phrases in the present tense, which illustrate 
actions and movements, and characters' physical aspect (174). That could be seen in Baricco's presentation of Gould's imaginary boxing matches.

According to Pavličić, intermediality refers to an educated reader who is able to understand and enjoy the characteristics of other media that are present in the literary text (175). The process of decoding that interrogates the text requires an involved reader (Wollen 163-64, 166)

From the narrative perspective, it is very significant that Baricco chose a western to create a story within the story and make it an aspiration of one of the main characters. Shatzy's western mentions some interesting facts, which could be related to postmodern literary work. Someone in the city has torn up time, and exactly at that moment all the gold in the city established for financial interests disappeared. The citizens had the choice to stay or not. At the end, it is revealed that the clock is safe.

Ewa Nicewicz explains the role of Closingtown, defined as a concept opposed to a place. In that town everything is repeated from day to day, and the clock reparation would introduce back the concept of time (Nicewicz 165). Just as the citizens have to patch time, a dedicated reader is able to deduct the story from the postmodern patchwork that has multiple layers. The postmodern patchwork offers to the reader an interesting image of a contemporary world and gives importance to some current problems.

The genre of western was designed to present the colonization of the Wild West (Peterlić, Povijest 218-19). It is more about just presenting a mentioned place and war, cowboys, lasso, jeans, cows and horses, the Mexican revolution, etc. (Škrabe 5). In relation to this paper and the importance of what the city may present, it is worth mentioning the dichotomy between civilization and wilderness (Čegir 28), which could find its reflection in the dichotomy between urban and rural areas.

According to Baudrillard, placing the novel in America, as the promised land, it is possible to present utopian ideas of dreams come true (qtd. in Nicewicz 162). Postmodern culture is, after all, believed to be metropolitan (qtd. in Nicewicz 200, 162).

There are some curiosities and facts about westerns as a film genre that are connected to the characters' personalities. They explain the meaning of the term 'city' from the perspective of this novel. In westerns there is a complex social organization, which also includes a codex of friendship 
and morality (Škrabe 8; Moan 50). Additionally, westerns are very dramatic because of the presence of combat between good and evil, which always brings the absolute triumph of one of them (Škrabe 11-13; Bogdanović 101; Peterlić, Povijest 219). Western heroes are usually very specific and isolated individuals. Some are more capable than the others, and even when they kill, they do it in order to eliminate evil, but in their relationships with women they are shy because they are meant to remain isolated individuals (Peterlić, Filmska 159; Škrabe 14-16).

These westerns' characteristics have their reflection in Shatzy's and Gould's characteristics. They are presented as good and isolated individuals who accidentally meet and become good friends. One of Gould's professors says that his student is the only honest person he has met. That is why Gould remains an isolated individual in the grown-up world, and his grown-up attitude does not let him be a child. In fact, he graduated at the age of eleven. However, he has no relationships with girls and does not take part in the world of adults. This can be confirmed by Shatzy's words in the novel:

... a genius who wets his bed at night and is afraid if someone on the street asks him what time it is, and hasn't seen his mother for years and listens to his father Friday night on the telephone, and will never go up to a girl even to pray... (Baricco 224)

In the following section we will explain why the term 'city' is crucial in the novel's interpretation. It will be pointed out that Shatzy Shell's western is placed in the western city named Closingtown. We will also focus on the two protagonists of Baricco's novel, and on fact that towns in the West present a complex social structure.

\subsection{The 'City' as a Construct of the Same-named Novel}

Bearing in mind that a city might be a "highly organized center of population" (Encyclopedia Britannica), this novel reveals all its complexity regarding its structure that includes intertextuality and intermediality, and the meaning construction. This complex postmodern patchwork ${ }^{[3]}$ has a precise structure where every single character or element has its role in the narration. 
According to Nicewicz, the characteristics of postmodern style (see: Ceserani 127) are fragmentary narration, abundant use of intertextuality, parody and pastiche, interchange of codes, random collection of materials, language, register and style mixture, the idea of literature as a game "that could end distinction of mass and elite culture." (Nicewicz 159)

Baricco has stated that while writing this novel he did not need to have in mind a specific city, but what a city might be:

A city. Not a precise city. Rather the footprint of any city. Its skeleton. I thought of the stories that I had in mind as certain neighborhoods. And I imagined the characters as if they were streets, and, at times, they were born and they died in a quarter, the others were crossing the whole city, threading together neighborhoods and worlds which have nothing to do one with another, and which all construct the same city. (Lo spazio).

According to Krešimir Purgar, Baricco's city presents a mental town where "boys geniuses, mutes who speak, prostitutes with philosophical ideas about life ${ }^{[4]}$ boxers who are moral examples, and eccentric professors" are placed. There is also an unfair survival battle between individuals who live in the world falling apart (Purgar 184-85).

An interesting interpretation written by Raspudić explains the existence of Gould's two imaginary friends. Diesel - a giant represents a metaphor of Gould's feeling of not belonging to the world of children, and the mute Poomerang is the reproduction of his isolation and the unrealized tentative to be included in the world of adults. Gould finds their world to be hypocritical. The author also explains why Gould and Shatzy become friends. It is because both of them come from families with complicated relations and history, and both of them live in their imaginary worlds. The one of Gould is related to boxing matches, and Shatzy's is related to composing a western. There is also the relation between Gould and his imaginary boxer. Gould is a genius in child age, and Larry Lawyer Gorman comes from a rich lawyer's family and is considered a stranger in the world of boxing (Raspudić 220-22). Gould's complicated family situation has already been mentioned, and Shatzy also has a very complicated relationship with her father, which does not improve until he leaves the family for his lover. In order to find something good in him, Shatzy has created her own exercise. She imagines her father as Hitler, and herself as Eva Braun because her mother told her that Eva 
Braun had been Hitler's daughter who loved him so much that she committed suicide in order not to live without him. In fact, Shatzy's father has not been mean to her, and he did not beat her but:

he worked and that was all, he did it, as if life had insulted him, and so he had withdrawn himself out of it; it was like a black hole, an abyss of unhappiness, and the tragedy, the real tragedy, the heart of all that tragedy was that he had dragged us down, totally, me and my mother, into that hole along with him, all he did was drag us down, every moment of his life, every instant, with a miraculous constancy... (Baricco 13)

In the book, some cities are mentioned, but the most important is the city named Closingtown. It is the city where Shatzy's western takes place. One of Shatzy's characters describes the city with these words: "We are a city of exiles, of people absent from themselves" (Baricco 283). The city was established on a territory where there "was nothing. Only Indians, in surrounding canyons, hidden in their invisible villages." (Baricco 291) The city was established when someone of present seventeen families found gold. It was decided that "[f]or five years they would work in the isolation from the world, then each would be able to go his own way, with his gold“" (Baricco 291).

There is an evident motif for having established this secret imaginary city -financial interest: "there was more [gold] in Closingtown than in all banks of Boston" (Baricco 292). In addition, there can be cultural and intellectual motifs to organize a city. That could bring us to the conclusion that Shatzy's imaginary city is the opposite of the cities where Gould lives. What they have in common is the term 'isolation'. His house may be considered as an abandoned city. It has two storeys, eight rooms, a garage and cellar (Baricco 23), but as he is considered a genius, he lives in college. Gould's university may also be considered as a city because of its organizational structure and the people who work there and frequent it. There is a part of the novel which illustrates how big the university is, and how small Gould:

Gould went through the gate and started out along the central path, across the big lawn. He didn't look back. He seemed very small, in the middle of that whole school; Shatzy though that she had never, in her whole life, seen anything smaller than that boy with his schoolbag, as he went along the path, becoming smaller and smaller with each step. (Baricco 51). 
This description illustrates a fragmented, weak subject that is characteristic of postmodern writing (Ceserani 141).

Gould initially lives at the university, where he also has to establish certain social relations. He fails that mission, remaining isolated. The isolation between people can reflect a contemporary city where there are a lot of facilities that might help people socialize, but, in fact, they remain isolated. It has been mentioned that to change yourself, you have to change the city you live in (Augé 10). Gould leaves the university - the only city and model he has known. That could be confirmed by Shatzy's words: "... a boy who has seen nothing but your ... classrooms and the road that leads to them" (Baricco 224). When Gould leaves his university, he starts living on his own in completely different circumstances. Instead of being admired as a genius, as a potential candidate to get a Nobel prize, he starts working in a shop's public toilet.

A "home" or extended "city where the people live" may be considered as a duality of two abstract and opposite concepts, those of life and death. As illustrated by Shatzy:

Not that something had changed in my mind: I still had stuck inside me that sensation of piercing, painful amazement, and in fact I would never again be without it, because when a child discovers there's a place that is his place, when his home flashes before him for a second, and the meaning of a Home, and, above all the idea that such a House exists, then it's forever, you've been screwed to the very end, there's no going back, you will always be someone who's passing through by chance, with a piercing, painful sense of amazement, and so you're always happier than others and always sadder, with all those things to laugh and cry about, as you wander (Baricco 40-41).

Shatzy's words again related to Ideal Home Exhibition reflect the meaning of the 'city' as a place that should make people feel safe and happy: "When you happen to see the place where you would be safe, you are always looking at it from the outside. You're never in it. It's your place, but you are never there" (Baricco 39).

The imaginary cities are shown to make people think what a city with all of the relations might be, as it is written in the novel: "inside you see things that, walking around the street, you dream of but in real life you'll never find. Real life never speaks. It's a game of skill, you win or lose, they make you play it to distract you, so you won't think" (Baricco 40). 
It has been mentioned that the novel presents what a city might be and that life is a "game of skill," which can remind us of postmodernism and postmodern linguistic games. Raspudić states that Baricco is an author that "even Italian literary critics do not hesitate to nominate as postmodern author" (Raspudić 208).

It has been written about the complexity of the novel that there are more motifs why Baricco's city exists. The most distinguished ones are intellectual and cultural. The author's intention of presenting what a city may be is faithfully represented in this part of the novel:

you had to imagine Closingtown as a man hanging out of window of a stagecoach with the wind in his face. The stagecoach was the World, which was making its nice journey through Time ...I could think of what was happening in my head as something not very different from Closingtown. (Baricco 278).

It has been mentioned that postmodern texts consist of multiple layers, given also the fact that there is intertextuality and intermediality. The concept of 'double coding' has been introduced by Margaret Rose and Linda Hutcheon. The concept is related to intertextuality, parody, irony, and double-talking (Ceserani 128). In view of this, it is to be mentioned that Claudio Pezzin has defined the novel City as a humoristic satire that is also "philosophical and grotesque and presents contemporary society" (Nicewicz 168). The success of the book confirms also that Baricco's imaginary city has distinguishing characteristics. The urban dictionary brings an explanation of the term 'city' used as an adjective: it is "a way to say something possesses a distinguishing attribute exceedingly" (Urban Dictionary). This, as we have seen, is reflected both in Baricco's protagonist and the whole novel.

\section{Conclusion}

The novel City written by Alessandro Baricco is considered to be his most complex novel. It has three different layers and also presents a story within a story with multiple meanings and interesting messages that can be deduced from the novel. 
The first layer is related to Shatzy's and Gould's lives. The second layer is presented by Gould's imaginary boxing matches, and the third one by the western that Shatzy creates. The novel discusses some very interesting contemporary issues like isolation in postmodern society, not only for citizens in a certain place but also for individuals in their family relations.

Also, there is a double postmodern language game in the novel. The first is related to Closingtown as a Western city and Shatzy's aspiration to write a western. Shatzy Shell's western incorporated in the novel is also important in relation to the term 'city' as westerns present different social relations cultivated in a certain area, and also present a contrast to an urban area. The second language game is related to the comparison of Closingtown to the postmodern text. Also, intertextuality and intermediality are present in the novel, and they, among other examples, include western. Someone in the town tore up time, which reflects fragmented narration. The narration is often interrupted by Gould's imaginary boxing matches that are an example of intermediality.

Different characters, whose relations are multiple, compose a postmodern patchwork. The characters are imaginary components of the imaginary city. A detailed analysis of the term 'city' shows that most of the attributes and definitions of the term 'city' find their reflection in the samenamed novel, such as the "place where people live," including its citizens. It can also be seen that postmodern cities are characterized by individuals who live solitary lives. It can be noticed that the population of a certain city is fragmented, and fragmentation is postmodern literary production.

Although there are some cities mentioned in the book, the most important is the city of Closingtown. It is mentioned in the novel and the central protagonist's Shatzy Shell's western presents an important town for its citizens. In addition, different characters both in the novel and Shatzy's book present different layers of the patchwork named "City" as a reflection of the big and important global town. Firstly, a "city" may be considered as the duality of life and death: this can be seen in Schatzy's discoveries while watching the Ideal Home Exhibition. Secondly, Gould, the boy genius, lives in a college which may be considered as a city, having in mind not only social relations established there but also that the "city" is the place where people live, which makes them feel safe and happy. In fact, he is a lonely boy and that presents the reality of contemporary cities where people are isolated individuals. He also changes, and with the change of the behaviour of citizens, the city changes too. Finally, there is also a literary reflection of the term 'city' considered 
as an adjective with the meaning of "something distinguishing." This reflection could be seen in Baricco's extraordinary book. In addition, the reasons why this literary city exists are both cultural and intellectual.

All of the above leads us to the conclusion that the novel reflects what a city in literature might be, and what an ideal city and an ideal text might be. Their intertextual connection reflects multiple layers that the novel has. They produce different meanings that a dedicated reader can deduct, and at the same time enjoy the process of discovering different genres and texts that are parts of the same novel. The city is the main motif of this novel, as confirmed by the mentioned cities, the selection of the title, and also by the term 'city' with all of its connotations and meanings that present one of the novel's constructive elements. This can be confirmed by the presentation of different characters who construct an imaginary city and the text of this novel. To conclude, Baricco's City is full of different meanings that are products of language games. To understand them, it is crucial to consider what the city may represent.

\section{Works Cited}

Augé, Marc. II bello della bicicletta. Translated by Valentina Parlato, Bollati Boringhieri, 2009.

Baricco, Alessandro. City. Translated by Ann Goldstein, Penguin Books, 2002.

Beker, Miroslav. "Tekst/Intertekst”. Intertekstualnost i intermedijalnost, edited by Zvonko Maković, et al., Zavod za znanost o književnosti, 1988, pp. 9-20.

Best, Steven, and Douglas Kellner. Postmodern Theory: Critical Interrogations. Macmillan, 1991. Bogdanović, Žika. Veliki vek filma. Epoha, 1960.

Cambridge Dictionary Online. Cambridge University Press, dictionary.cambridge.org/. Accessed 14 Aug. 2018.

Čegir, Tomislav. Filmski prostori: hrvatske rekonstrukcije američkog žanrovskog filma. Hrvatsko društvo filmskih kritičara, 2012.

Ceserani, Remo. Raccontare il postmoderno. Torino: Bollati Boringhieri, 1998. 
Chambers 21st Century Dictionary. Hodder \& Stoughton Ltd., chambers.co.uk/search. Accessed 14 Aug. 2018.

Collins English Dictionary. Collins, www.collinsdictionary.com/. Accessed 14 Aug. 2018.

Encyclopaedia Britannica. Encyclopaedia Britannica, Inc., www.britannica.com/. Accessed 14 Aug. 2018.

Gulin Zrnić, Valentina. "Antropološka istraživanja grada”. edited by Setha M. Low, translated by Martina Maričić, Naklada Jesenski i Turk, 2006, pp. 7-15.

Infoplease Dictionary. FEN Learning, www.infoplease.com/. Accessed 14 Aug. 2018.

Kečkemet, Duško. Grad za čovjeka - o dehumanizaciji suvremenog urbanizma. Zrinski, 1981.

Kusik, Vlastimir. Adresa - Eseji, kritike, kolumne i ostalo. Matica hrvatska, Ogranak Osijek, 2007.

Lachmann, Renate. “Intertekstualnost kao konstitucija smisla: Petograd Andreja Belog i 'tuđi' tekstovi”. Intertekstualnost i intermedijalnost, edited by Zvonko Maković, et al., Zavod za znanost o književnosti, 1988, pp. 75-108.

Lo spazio web Rizzoli. 3 July 2016, www.labcity.eu/. Accessed 16 Aug. 2018.

Low, Setha M. "Smještanje kulture u prostoru: Društvena proizvodnja i društveno oblikovanje javnog prostora u Kostarici". Promišljanje grada: Studije iz nove urbane antropologije, edited by

Setha M. Low, translated by Martina Maričić, Naklada Jesenski i Turk, 2006, pp. 91-123.

Macmillan Dictionary. Macmillan Education Limited, 2009, www.macmillandictionary.com/. Accessed 14 Aug. 2018.

McDonogh, Gary. "Diskursi o gradu: Politika i reakcije na politiku u posttranzicijskoj Barceloni”. Promišljanje grada: Studije iz nove urbane antropologije, edited by Setha M. Low, translated by Martina Maričić, Naklada Jesenski i Turk, 2006, pp. 217-60.

Merriam-Webster Dictionary. Merriam Webster, Incorporated, www.merriam-webster.com/. Accessed 14 Aug. 2018.

Moan, Rafaela. Filmski žanrovi. Translated by Aleksandar Luj Todorović. Clio, 2006. 
Nicewicz, Ewa. "Nei labirinti dello spazio cittadino - City di Alessandro Baricco." Études romanes de Brno, vol. 30, no. 1, 2009, pp. 159-69

Online Etymology Dictionary. Douglas Harper, 2001, www.etymonline.com/. Accessed 14 Aug. 2018.

Pavličić, Pavao. “Intertekstualnost i intermedijalnost: Tipološki pregled”. Intertekstualnost i intermedijalnost, edited by Zvonko Maković, et al., Zavod za znanost o književnosti, 1988, pp. 15788.

Peterlić, Ante. Filmska čitanka Ante Peterlića: žanrovi, autori, glumci, edited by N. Gilić, et al., Hrvatski filmski savez, 2010.

Peterlić, Ante. Povijest filma: rano i klasično razdoblje, edited by Nikica Gilić, Hrvatski filmski savez, 2008.

Purgar, Krešimir. Slika u tekstu. Talijanska i američka književnost u perspektivi vizulanih studija. Durieux, Hrvatska sekcija Aica, 2013.

Raspudić, Nino. Slaba misao - jaki pisci: Postmoderna i talijanska književnost. Naklada Jurčić d.o.o., 2006.

Škrabe, Nino. Vestern - filmovi, ljudi, legende. Slavica film, Centar za kulturu radničkog sveučilišta Đuro Salaj, 1979.

Šojat-Kuči, Ivana. I past će sve maske... (eseji). Alfa, 2006.

The American Heritage Dictionary of the English Language. Houghton Mifflin Harcourt, www.ahdictionary.com/. Accessed 14 Aug. 2018.

Urban Dictionary. Urban Dictionary, 1999, www.urbandictionary.com/. Accessed 14 Aug. 2018. Vocabulary.com Dictionary. Vocabulary.com, www.vocabulary.com/. Accessed 14 Aug. 2018. Wollen, Peter. Sings and Meaning in the Cinema, New and Enlarged. Indiana University Press, 1972.

Wordnik. Wordnik, www.wordnik.com/. Accessed 14 Aug. 2018. 
Wordsmyth - The Premier Educational Dictionary-Thesaurus. The Wordsmyth Organization, www.wordsmyth.net/. Accessed 14 Aug. 2018.

Your Dictionary. LoveToKnow, www.yourdictionary.com/. Accessed 14 Aug. 2018. 
[1] For the novel's structure, see: Purgar 171.

[2] There is an interesting cinematical interpretation of the novel written by Krešimir Purgar (Purgar 165-91).

[3] The term is introduced by Jean-François Lyotard (see: Best and Kellner 159).

[4] In fact, in Shatzy's western there is a story of a prostitute who used to be a teacher and reads a lot, and Baricco's book presents some very interesting individuals who are Gould's university professors.

\section{(c) (i) (9)}

Creative Commons Attribution-NonCommercial-NoDerivatives 4.0 International License 